\title{
, \\ COVID-19 Pandemic, Technological Progress and Food Security Based on a Dynamic CGE Model
}

\author{
Xinyue Lin ${ }^{1}$, Lingli Qi ${ }^{2, *}$, Haoran Pan ${ }^{3}$ and Basil Sharp ${ }^{2}$ \\ 1 School of Economics and Resource Management, Beijing Normal University, Beijing 100875, China; \\ lin_xinyue@mail.bnu.edu.cn \\ 2 Energy Center, University of Auckland, Auckland 1010, New Zealand; b.sharp@auckland.ac.nz \\ 3 Center for Innovation and Development Studies, Beijing Normal University, Zhuhai 519087, China; \\ hrpan@bnu.edu.cn \\ * Correspondence: lingli.qi@auckland.ac.nz
}

Citation: Lin, X.; Qi, L.; Pan, H.; Sharp, B. COVID-19 Pandemic,

Technological Progress and Food

Security Based on a Dynamic CGE

Model. Sustainability 2022, 14, 1842.

https://doi.org/10.3390/su14031842

Academic Editor: Riccardo Testa

Received: 29 December 2021

Accepted: 1 February 2022

Published: 5 February 2022

Publisher's Note: MDPI stays neutral with regard to jurisdictional claims in published maps and institutional affiliations.

Copyright: (C) 2022 by the authors. Licensee MDPI, Basel, Switzerland. This article is an open access article distributed under the terms and conditions of the Creative Commons Attribution (CC BY) license (https:/ / creativecommons.org/licenses/by/ $4.0 /)$.

\begin{abstract}
The global spread of COVID-19 has complicated the international equilibrium of grain production and trade. China now faces external shocks in the international grain market and deepseated problems associated with the structure of domestic supply. We used a dynamic, computable general equilibrium (CGE) model to analyse the effects on China's food security and macroeconomics under the COVID-19 scenario and four technological progress paths in the agricultural sector. We showed that the COVID-19 pandemic is disrupting China's food security in the short term, and critical quantitative variables such as grain production and grain consumption per capita have declined. Considering food security and macroeconomic development, labour-saving technological progress outperformed neutral technological progress, land-saving technological progress, and capital-saving technological progress in the short run. While land-saving technological progress contributes the most to the arable land area per capita of wheat and other grains in the long run.
\end{abstract}

Keywords: COVID-19; technological progress; food security; CGE model

\section{Introduction}

Coronavirus disease 2019 (COVID-19) has spread globally and disrupted agricultural production throughout the world [1]. Many countries have adopted extreme measures to control the spread of the virus, including social distancing, closures of schools and nonessential businesses, border restrictions, and nationwide quarantines [2]. The lockdown measures, though essential to decrease the loss of life, are creating massive pressure on economic operations and adversely affect food security and hunger [3-6]. COVID-19 has had a significant impact on global agricultural production and international transportation, sales, and trade, which has exacerbated global market turmoil and the imbalance of supply and demand [7]. Besides, labour is the primary input factor of agricultural production and tends to suffer the most during a period of public health concern [8]. The economic and social impacts, and the likelihood of continuing infections, will play a role over the longer term, with concomitant effects on the food and agriculture industries [9].

The global target of eliminating hunger is challenging, as even before the COVID-19 pandemic, approximately 1.9 billion people struggled to access food or were worried about a healthy diet $[10,11]$. According to the World Bank, a hunger pandemic could quickly follow the COVID-19 pandemic, doubling severe food insecurity and putting an additional 40-60 million people in extreme poverty [12]. Therefore, it is profoundly necessary to consider the related issues of food security during the pandemic crisis.

The COVID-19 pandemic has threatened food security in all the affected economies. China has a large population, and food security is of great significance to China's economic development and social stability $[13,14]$. Before the outbreak of COVID-19, Mukhopadhyay, et al. [15] pointed out that China's agricultural productivity was lower 
than the world average, resulting in lower agricultural outputs and tremendous pressure on China's food security goals. Moreover, with rapid urbanization, the farmer population decreased and food insecurity issues have become an obstacle to sustainable development due to the limitation of arable land and population growth [16]. In February 2020, the Central Committee of the Communist Party of China issued the "No. 1 Document", which clearly stated that "Ensuring food security is always the top priority of governance. Grain production must be stable, with stable policies, stable arable areas, and stable yields" [17]. In the context of COVID-19, the primary risks to food security are at the national level, since the combined impacts of COVID-19 disruptions and other existing issues are changing food security in China. Therefore, it is urgent to understand the challenges posed by COVID-19 from a macro perspective and provide some insights for strengthening the resilience of food systems over longer time horizons.

In response to the COVID-19 pandemic, promoting agricultural technological progress is critical for ensuring China's food security and sustainable agricultural development in the future. The improvement of technological progress is an important factor contributing to China's economic growth [18]. However, analyses of the agriculture sector have seldom comprehensively explored the effects of technological progress on promoting the advancement and sustainability of food security. In this article, we adopted a recursive dynamic CGE model to analyse the impact of technological progress on agricultural food security in the context of the COVID-19 pandemic. The purpose of using a recursive dynamic CGE model is to estimate how the variables of interest change over time. Changes in endogenous variables or shocks of exogenous variables caused by consumers, producers, government, and other agents' behaviour in the economy can shift one equilibrium status to another during the time [19]. This study complements existing studies in three aspects. First, our study introduced the impacts of the COVID-19 shock and focused on the impacts of COVID-19 on agricultural production and food security, including technological progress. Second, based on a dynamic CGE model, this study incorporates total factor productivity (TFP), labour-saving, capital-saving, and land-saving technological progress into a unified research framework. It is more conducive to a macroscopic analysis of the impact of technological progress on food security. Last but not least, this study built a food security indicator system to reflect food insecurity better and distinguish which types of technological progress perform well. This research found that labour-saving technology affects food security the most and provides some policy recommendations for ensuring China's future food security in the context of the current pandemic.

The remaining contents are arranged as follows. Section 2 presents a literature review. Section 3 describes the modelling framework and provides a detailed description of how the COVID-19 pandemic caused a shock to the economy. Section 4 presents the impacts of COVID-19 and agricultural technological progress on food security in the short and long run. Section 5 concludes with policy implications and recommendations for further study.

\section{Literature Review}

Some recent literature has reported the impact of COVID-19 on agriculture using traditional research methods, such as qualitative analysis or questionnaire surveys [20-22]. In China, Pu and Zhong [23] discussed the impact of COVID-19 on China's agricultural production and the government's response measures to mitigate its negative impact. Deng, et al. [24] collected survey data from 8031 farming households in 27 provinces in mainland China to provide an empirical basis to help policymakers reduce the negative impact of COVID-19 on food security. In other countries, similar studies have been conducted, such as a case study in India [25]. The consecutive application of the autoregressive distributed lag method and Yamamoto's causality test, and a variance decomposition analysis of 45 developing economies [6]. However, due to sample limitations and the subjectivity of the research methods, it is impossible to track the dynamic impact of COVID-19 on the whole agricultural economy and analyse the effect of the anti-pandemic measures on agricultural production. 
CGE models are useful for evaluating policy options by identifying the economic changes through which the direct effects of the COVID-19 outbreak can be revealed [26]. Nechifor, et al. [27] adopted the CGE model with a food security and nutrition (FS\&N) microsimulation module to assess the impacts of COVID-19 on economic and food security based on the shock paths of the pandemic from the perspectives of labour productivity, export demand and tourism, remittances, internal demand, and internal trade costs. Liang, Qin, Jiang, Wang and Shi [8] used a dynamic CGE model to study the impact of epidemic-affected labour shortages on agricultural production in China. The results show that agricultural production will be less affected by the local control of the epidemic situation than previously thought. The output of agricultural products fell by about $2.19 \%$, and the prices of agricultural products rose slightly. While the national production of agricultural products fell only by $0.1 \%$, prices remained stable. Compared with the nationwide outbreak, the local spread level has a smaller impact on China's food security, meaning China's policy to combat the epidemic is effective. Other CGE models used to assess the agricultural impacts of COVID-19 in China include those of Beckman and Countryman [28]; Han, et al. [29]; and Zhang, et al. [30].

How to ensure food security in the context of the COVID-19 pandemic has become the focus of attention at present. Technological progress can work to alleviate the impact. Total factor productivity (TFP) growth is typically understood as technological progress [31]. Various inputs can reflect TFP growth, and better-quality inputs being more productive [32]. It is a phenomenon that Hicks [33] described as biased technological progress. He stated that the inherent meaning of technological progress is to use more abundant input factors and save more scarce factors. Progress can be categorised into four detailed types: capital-saving, labour-saving, land-saving, and TFP progress [34]. Up until the later stages of industrialisation, academic research on biased technological progress gradually increased [34-36], along with research on different growth patterns in technological progress between sectors [37-39].

Research has evaluated the effects of technological progress on agricultural production with a variety of results. For example, using a DEA approach to model the dynamic of factor inputs, Chen, et al. [40] suggested that capital and land productivity have dominated China's wheat production instead of labour-intensive operations. However, Key [41] found that labour-saving technologies enabled farms in the United States to produce on a larger, more productive scale. Zhang, et al. [42] analysed the labour-saving and capital-saving technological progress in China's food production in different regions with a multi-regional CGE model. The results showed that labour-saving progress leads to a greater increase in food production than capital-saving progress. Other research on the agricultural sector has used the CGE model from the perspective of increased factor productivity [43] and improvements in land management [12].

However, few studies have used CGE to study the impact of the COVID-19 pandemic and technological progress on food security in China. This study went beyond the limitations mentioned in the literature review, focusing on the impacts of COVID-19 on agricultural production and food security, combined with technological progress. First, we incorporated neutral technological progress, labour-saving, capital-saving, and land-saving progress into a unified research framework of China's CGE model. Second, we evaluated the different effects of four types of technological progress on food security in the context of the COVID-19 pandemic. We designed a new approach to studying progress in agricultural technology during public health crises. Specifically, our study introduced the COVID-19 impact and agricultural technological progress into the model, focusing on the technological growth of different paths and constructing an indicator system for testing food security to achieve high-quality sustainable development. 


\section{CGE Modelling Framework and Data Input}

\subsection{CGE Model}

The CGE model was initially developed by Johansen [44]. It is used to study the overall economy and its response to changes in external shocks, and the supporting data are in the form of a social accounting matrix (SAM) table. We adopted a dynamic CGE model to simulate the COVID-19 shocks and evaluate the long-term and short-term impacts of different types of technological progress on food security and macroeconomic effects. As shown in Figure 1, the model includes production, expenditure and income, investment, trade, closure, and dynamic modules. The CGE model equations are presented in Appendix A.

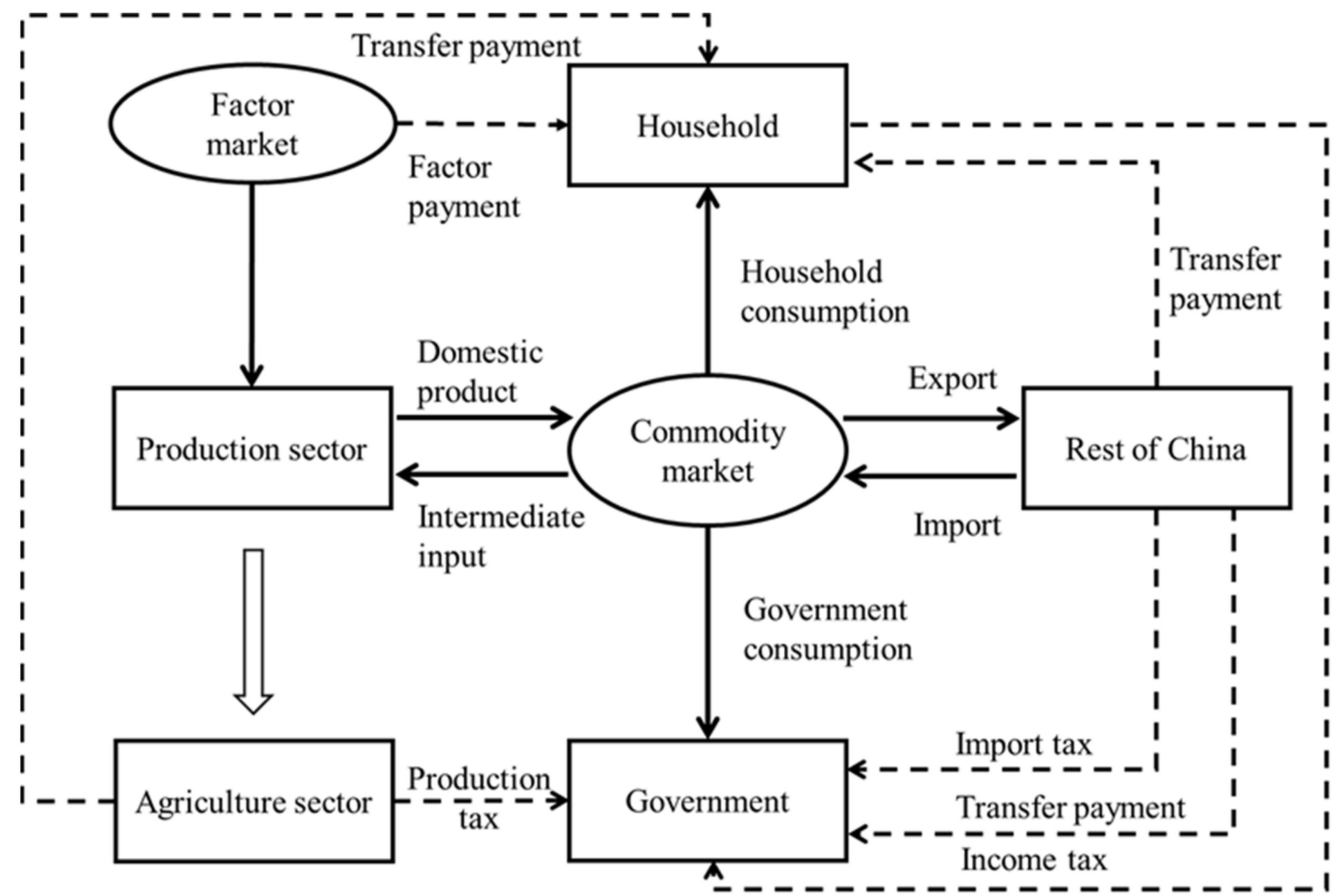

Figure 1. Framework of the CGE model.

The production module describes the relationship between factor inputs and domestic outputs. According to the substitution relationship between inputs, it is usually divided into three categories: Leontief production technology, Cobb-Douglas production technology, and constant elasticity of substitution (CES)production technology. This model assumes that the market is completely competitive and that production decisions are made following the principle of cost minimization. To reflect and solve the more complex substitution relationship between multiple inputs, the production module uses a multi-level nested form (See Figure 2). The intermediate input and compound factors (value-added) solve the first level of nesting through the CES function. The second layer comprises the following two parts. The first part is the compounding of intermediate inputs through the Leontief (LT) function, and the second part is the compounding of capital, labour, and land factors through the CES function.

Households and the government maximize their utility from the consumption of the final goods by following a Cobb-Douglas utility function in the income and expenditure module. Household income is used for consumption or savings and is derived from compensation of all primary factors and transfers from the government. The government's income is composed of various taxes and transfer payments from the rest of the world, and its expenditures include purchases, transfer payments, and the surplus.

International trade is a significant module of this model. Armington's assumption is applied to combine imported goods with domestic goods, representing imper- 
fect substitution with different elasticities. At the same time, the total domestic output is distributed between domestic use and exports through a constant elasticity of transformation (CET) function.

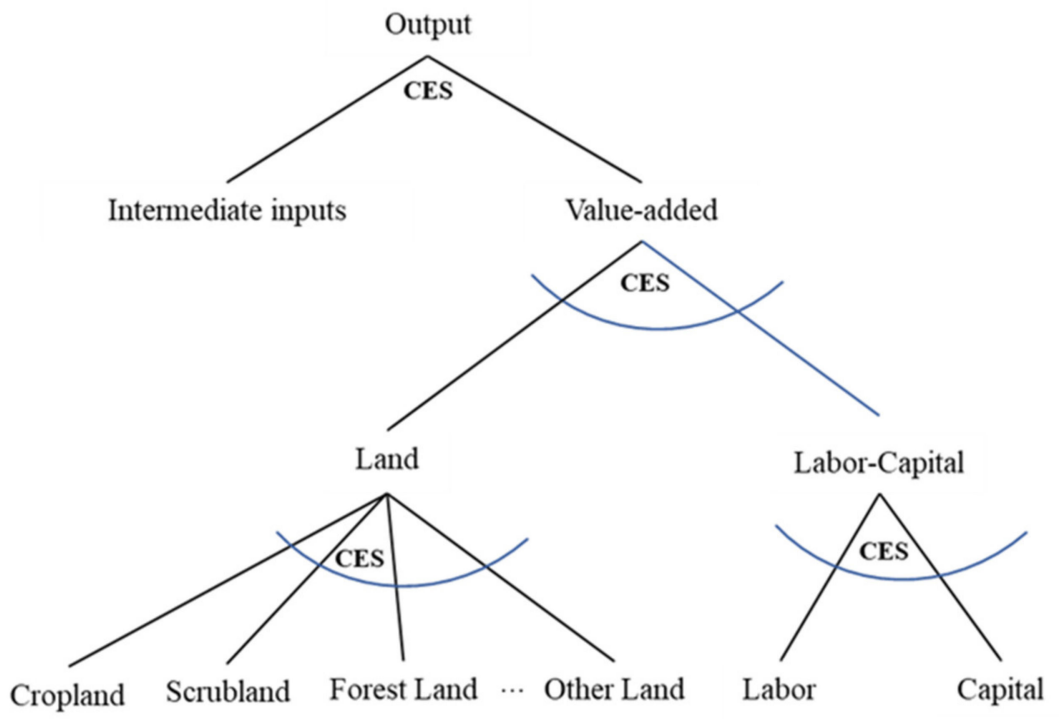

Figure 2. The nesting structure of the production module.

This model was used to simulate the dynamic trends in agricultural economic growth and food security brought about by technological progress and macroeconomic changes from 2020 to 2030. To achieve this goal, we used a recursive dynamic mechanism that operates through the dynamic changes of labour force growth and capital accumulation to achieve the equilibrium of the new model. The data on the growth rate have been taken from the "World Population Outlook 2017", released by the Population Division of the United Nations Department of Economic and Social Affairs [45].

To gain a unique solution, the CGE model needs to set the micro-closure and macroclosure to ensure that the constraining conditions are consistent with the number of endogenous variables. We obtain the equilibrium price under market equilibrium conditions, which represents the solution of the nonlinear equation system. The nonlinear equation system includes the intermediate and final demand equations, the expenditure and income equations of households and the government, savings and investment equations, and trade balance equations. We used neo-classical closure, setting closures in the commodity markets, the factor markets, institutional income and expenditure, trade markets, and investment savings.

\subsection{Data Input}

The CGE model has the following two parts: equations describing the model variables and a database consistent with the model equations. The database usually consists of a table of transaction values that are presented as an input-output table or as a social accounting matrix (SAM). The SAM table is a general equilibrium data system that links all the basic accounting identities, namely production activities, factor and commodity markets, institutions (firms, households, and the government), foreign trade (rest of the world, ROW), and other accounts (markets for loanable funds), to capture the circular interdependence of the nationwide economic system [46].

Here, we constructed China's social accounting matrix (SAM table) for 2017 based on the research requirements. The data were taken from the National Input-Output Table of 149 Sectors 2017, China Fiscal Yearbook 2018, China Tax Yearbook 2018, China Rural Statistics Yearbook 2018, China Trade and Foreign Economic Statistics Yearbook, and the Compilation of National Agricultural Product Cost and Profit Data 2018 (The construction of the SAM table is according to the guidelines provided in February 2020 by the Center of 
Economic Systems Simulation Research in China). The SAM table constructed in this study includes sectors, commodities, factors (labour, capital, and land), institutions (residents and the government), the rest of the world, and investment and savings. In order to study China's main food products precisely, we established the following settings in the production activity account and the factor account. First, in the activity and commodity accounts, the agricultural product sector was explicitly divided into rice, wheat, other grains, vegetables and nuts, oilseed crops, sugarcane, plant fibre, and other crops. Second, in the factor account, a land account was added, based on the arable area of the main crops. The land factor input was calculated on the basis of the land rents and arable land area and then deducted proportionally from capital investment.

\subsection{Food Security Indicator}

Due to the complexity of food security issues, it is not easy to measure food security with a single indicator. This study refers to the research of Ma, et al. [47], and Fan [48]. From the perspectives of quantity security, economic security, and resource security, we used six indicators to examine the level of China's food security under different technological progress paths in the context of COVID-19 to meet the goals of the new era of food security. The six indicators are shown in Table 1 below.

Table 1. Food security indicators.

\begin{tabular}{ccc}
\hline Indicator & Variable & The Nature of Indicators \\
\hline Grain output & $\mathrm{X}_{\mathrm{a}}$ & Positive \\
Arable land area per capita & $\mathrm{LDD}_{\mathrm{a}} / \mathrm{POP}$ & Positive \\
Grain consumption per capita & $\mathrm{QC}_{\mathrm{c}} / \mathrm{POP}$ & Positive \\
Grain price & $\mathrm{PC}_{\mathrm{c}}$ & Positive \\
Import dependence & $\left.\mathrm{QMc} / \mathrm{QD}_{\mathrm{c}}+\mathrm{QM}_{\mathrm{c}}\right)$ & Negative \\
Grain output per hectare & $\mathrm{Xa} / \mathrm{LDD}_{\mathrm{a}}$ & Positive \\
\hline
\end{tabular}

Here, $X_{a}$ is the total output of sector $a$; $\operatorname{LDD}_{a} / P O P$ is the land area per capita of sector $\mathrm{a} ; \mathrm{QC}_{\mathrm{c}} / \mathrm{POP}$ indicates all products c consumed per capita in the domestic market, including domestic production and imports; POP is the population; $\mathrm{PC}_{\mathrm{c}}$ is the price at which consumers purchase product $c . \mathrm{QM}_{\mathrm{c}} /\left(\mathrm{QD}_{\mathrm{c}}+\mathrm{QM}_{\mathrm{c}}\right)$ indicates the proportion of the imported volume of product c within total domestic consumption, where $\mathrm{QM}_{\mathrm{c}}$ is the imported volume of product $c$, and $\mathrm{QD}_{\mathrm{c}}$ is the domestic output of product $\mathrm{c}$ used for the domestic market. $X_{a} / L_{D D}$ is negative, which means that the larger it is, the greater the possibility of food security.

\section{Scenario Settings}

The cumulative impact of the COVID-19 epidemic has put the entire world under threat of food security and nutritional deficiencies, particularly in countries with large populations [49]. As the world's largest food consumer, China continues to hold a leading position in the global food supply chain [50]. In order to prevent the large-scale spread of the epidemic, the Chinese government has implemented a strict lockdown policy since the outbreak of COVID-19 to restrict the mobility of people. COVID-19 and its mitigation measures have affected agriculture in the following two relevant aspects: the supply and demand for food (See in Figure 3). On the one hand, direct and indirect effects of sickness and death have caused a reduction in labour supply and wage income, thus disrupting the planting and harvesting of agricultural commodities. On the other hand, these restrictions lead to a lag in the transportation of agricultural products. A sudden decline in the demand for agricultural products resulted in a large amount of unsellable seasonal perishable vegetables and fruits due to the closure of local restaurants and markets [51]. If such problems cannot be properly resolved, farmers will not be able to receive any profit from the current harvest (i.e., foods are backlogged in the farmland and will not even be picked), causing lower reinvestment in the next spring's planning. 


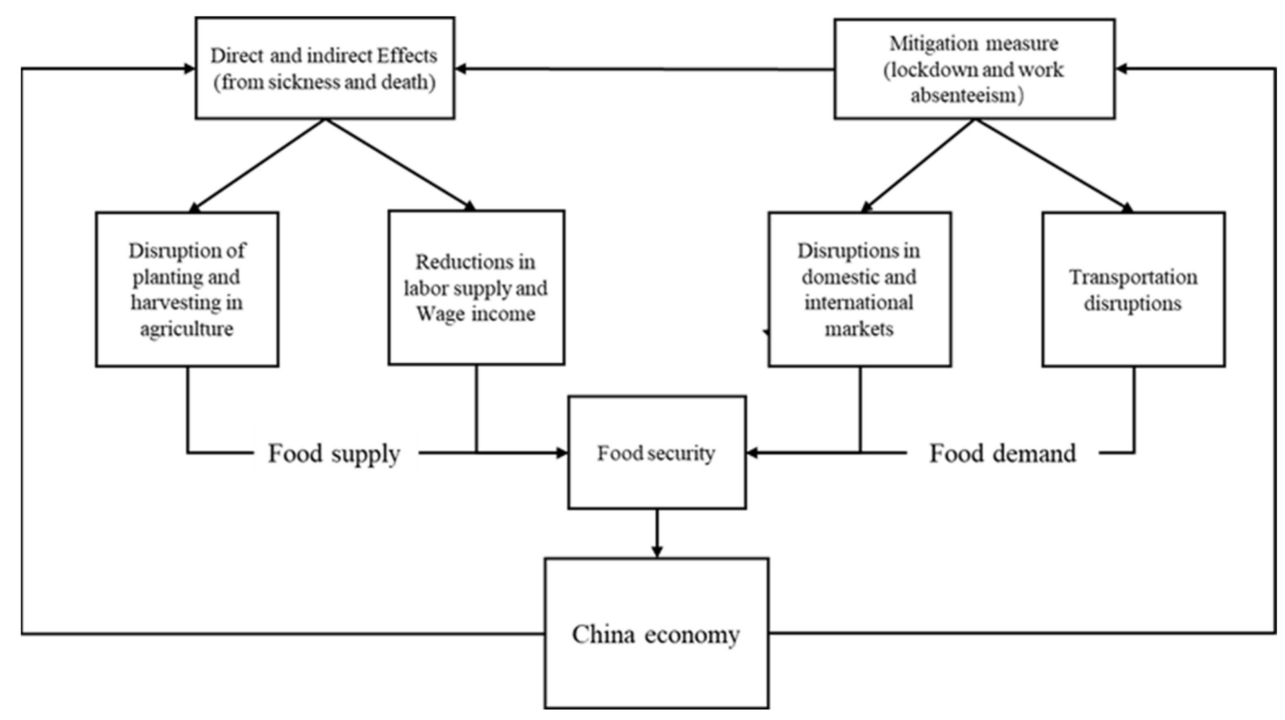

Figure 3. The COVID-19 impact on food security and China economy.

We refer to the methods of Dixon, et al. [52] and McKibbin and Fernando [53] to establish three main impact paths of the COVID-19 pandemic.

$\lambda \quad$ The shocks to the labour supply.

$\lambda$ The shocks to the output of sectors.

$\lambda$ The shocks to the international trade.

\subsection{Shocks to the Labour Supply}

The epidemic and quarantine policies have caused a decline in the labour supply. According to the latest data released by the National Health and Construction Commission, 82,067 cases have been cured by 31 December 2020, but a total of 4634 people have died [54]. It is assumed that the total time lost for diagnosis and treatment of the cured population is 4 weeks. Besides, according to data released by the National Bureau of Statistics, the national urban unemployment rate rose by $0.5 \%$ on average compared to last year. The workforce at the legal age in 2020 was 929 million, and the labour participation rate was $65 \%$. Suppose that the average working hours of employees in enterprises across China is $47 \mathrm{~h}$ a week, and 50 weeks a year.

$$
\rho_{\mathrm{LS}}=\frac{\sum \mathrm{LS}_{\mathrm{affect}} * \mathrm{HOUR}_{\mathrm{affect}}+\sum \mathrm{LS}_{\mathrm{loss}} * \mathrm{HOUR}_{\text {loss }}}{\mathrm{LS} * \mathrm{HOUR}_{\mathrm{total}}} \cdot 100 \%
$$

Among them, $\rho_{\text {LS }}$ represents the percentage of labour supply affected by the pandemic, $\mathrm{LS}_{\text {affect }}$ represents the labour force affected by treatment and lockdown during COVID-19, $\mathrm{LS}_{\text {loss }}$ means the dead and unemployment cases caused by COVID-19, respectively. Hence, the percentage of labour supply has decreased by approximately $2.26 \%$.

\subsection{Shocks to the Output of Sectors}

The total factor productivity is changed by setting the disaster variable $\varphi(P S)$, thereby affecting the output [55]. According to the latest economic data released by the National Bureau of Statistics, the negative impact of the pandemic on China growth in 2020 was massive, with only a $2.3 \%$ gross domestic product (GDP) growth, while GDP growth was $6.0 \%$ in 2019 [56].

$$
\varphi(P S)=\left(1-\frac{X_{i}^{*}}{X_{i}^{0}}\right) * 100 \%
$$

Among them, $X_{i}^{0}$ represents the expected output value of industry I in 2020 without the impact of the COVID-19 pandemic, and $X_{i}^{*}$ represents the actual output value in 2020. 
We combine 2020's GDP with the World Bank's forecast of China's 2020 GDP issued by the National Bureau of Statistics to obtain the hypothetical GDP and simulate each industry's GDP in 2020 [56]. It is calculated that the output efficiency of the primary industry decreased by $4.9 \%$, the output efficiency of the secondary industry decreased by $3.8 \%$, and that of the tertiary industry decreased by $3.5 \%$ compared with non-COVID levels.

\subsection{Shocks to the International Trade}

The export demand has been impacted by the economic slowdown of all China's major trading partners and strict restrictions on international travel. It shows that the world's economic growth in 2020 dropped by 4.3\%, compared with 2019 (2.9\%). The negative change is more than 7\%. According to the weighted average of China's industry export to each country and their actual economic development, we can estimate the changes in industry export demand. The decrease rate of the agriculture sector is $9.36 \%$ compared with the non-COVID level. The percentage change of imports is $-7.67 \%$ in the agriculture sector, $-28.04 \%$ in the mining sector, and $2.31 \%$ in the manufacturing sector.

\subsection{Technological Progress}

According to the characteristics of agricultural development, technological progress is divided into labour-saving technological progress, capital-saving technological progress, land-saving technological progress, and TFP growth. We draw on the method used by Acemoglu [34] to set technical coefficients. Here, we assumed that technological progress is cost neutral, which means the total technical cost remains unchanged, and only the cost allocation is changed in different paths of technological progress.

$$
V(P S)=A V(P S) *\left[\sum_{f} \gamma(f, P S) * \theta(f) * v^{\prime}(f, P S)^{\rho(P S)}\right]^{\frac{1}{\rho(P S)}}
$$

where, $V(P S)$ is the bundle of the added value of industries, $v^{\prime}(f, P S)$ represents the input of factor $\mathrm{F}$ in industries, $A V(P S)$ is total factor productivity, and $\gamma(f, P S)$ is the share parameter of factor $\mathrm{F}$ used by industries in the CES function. $\rho(P S)$ is the substitution coefficient between factors. We use $\theta_{f}$ to represent the biased technological progress rate of factor $\mathrm{f}$. Therefore, we simulated the progress of agricultural technology in four different situations by changing $A V(P S)$ and $\theta(f)$. In this study, we established the following types of technological progress: SET1 is labour-saving technological progress by $2 \%$; SET2 is capital-saving technological progress by $2 \%$; SET3 is land-saving technological progress by $2 \%$; SET4 is neutral technological progress by $2 \%$.

\section{Result Analysis}

\subsection{The Impact of the COVID-19 Pandemic on Food Security}

As shown in Table 2, the pandemic has impacted China's food security in the short term. Compared with the result of the BAU scenario without COVID-19, from the perspective of time, the epidemic's impact has a certain degree of delay. It broke out in 2020, and the fluctuations of various indicators will peak in 2021 and ease in 2022. It can be seen that there will not be severe food security problems in the short-term since China has a very high rate of cereal sufficiency. Until 2025, the rate of change compared with BAU will be small (below 0.01\%). This means, that without the influence of external shocks (such as government subsidies, food policies, technical support, etc.), the epidemic's impact on China's food security indicators will continue for 3-5 years. We found that these effects are mainly caused by some highly import-dependent agricultural products, such as soybeans, which is in line with the conclusions of Yao, et al. [57].

Specifically, under the COVID-19 shock, the trends in food security indicators such as rice, wheat, and other grains are almost the same. Compared with other indicators, the rate of change in arable land is the smallest. The reason for this, in our view, is that arable land is difficult to adjust because of the impact of external shocks in the short 
term. The output of rice, wheat, and other grains in 2020 decreased by $1.89 \%, 2.08 \%$, and $0.93 \%$ annually. The loss is more severe than the conclusions of NHC [54], since they only studied the impact of epidemic-affected labour shortages without the loss of productivity. Grain consumption per capita decreased by $1.90 \%, 2.13 \%$, and $1.01 \%$, arising from the strict lockdown and the sudden shutdown of restaurants, local markets, and caterers. Besides, grain prices increased by $4.03 \%, 1.69 \%$, and $1.40 \%$ due to the shortage of grain supply; import dependence decreased by $5.41 \%, 2.36 \%$, and $1.97 \%$; the grain output per hectare dropped by $2.23 \%, 2.88 \%$, and $2.96 \%$. In general, the indicators of rice, wheat, and other grains showed a downward trend during 2020-2022 due to COVID-19 without any policy implementation.

Table 2. The impact of the COVID-19 epidemic on food security indicators compared with BAU (\%).

\begin{tabular}{|c|c|c|c|c|}
\hline Indicator & Sector & 2020 & 2021 & 2022 \\
\hline \multirow{3}{*}{ Grain output } & Rice & -1.89 & -4.23 & -1.38 \\
\hline & Wheat & -2.08 & -3.66 & -1.19 \\
\hline & Other grains & -0.93 & -3.96 & -1.29 \\
\hline \multirow{3}{*}{$\begin{array}{c}\text { Arable land area } \\
\text { per capita }\end{array}$} & Rice & 0.34 & -0.99 & -0.32 \\
\hline & Wheat & 0.82 & -0.12 & -0.04 \\
\hline & Other grains & 2.08 & -0.56 & -0.18 \\
\hline \multirow{3}{*}{$\begin{array}{l}\text { Grain consumption } \\
\text { per capita }\end{array}$} & Rice & -1.90 & -4.23 & -1.38 \\
\hline & Wheat & -2.13 & -3.70 & -1.20 \\
\hline & Other grains & -1.01 & -4.09 & -1.33 \\
\hline \multirow{3}{*}{ Grain price } & Rice & 4.03 & 3.18 & 1.02 \\
\hline & Wheat & 1.69 & 2.18 & 0.70 \\
\hline & Other grains & 1.40 & 2.56 & 0.82 \\
\hline \multirow{3}{*}{ Import dependence } & Rice & -5.41 & -4.05 & -1.35 \\
\hline & Wheat & -2.36 & -3.02 & -0.99 \\
\hline & Other grains & -1.97 & -3.53 & -1.16 \\
\hline \multirow{3}{*}{$\begin{array}{c}\text { Grain output per } \\
\text { hectare }\end{array}$} & Rice & -2.23 & -3.27 & -1.06 \\
\hline & Wheat & -2.88 & -3.54 & -1.15 \\
\hline & Other grains & -2.96 & -3.42 & -1.11 \\
\hline
\end{tabular}

\subsection{The Impact of Technological Progress on Food Security}

It is necessary to study the mitigating effects of technological progress on food insecurity caused by COVID-19 and explore more targeted food security countermeasures. For example, in Figure 4a, under the implementation of labour-saving technological progress (Scenario SET1), the average annual growth in output of rice, wheat, and other grains in the short term is $3.40 \%, 3.49 \%$, and 3.41\%, respectively. In the SET3 scenario, the results are very similar to those of SET2. Labour-saving progress (SET1) appears to lead to a greater increase in food production than capital-saving and land-saving progress (SET2 and SET3) in Figure $4 b, c, e, f$. This result is consistent with Antonelli and Quatraro [58]'s opinion that factor-saving technological progress that matches the factor endowment structure can enhance agricultural output and TFP. China's farming area is smaller than that of some developed countries, such as the USA and France, but has a larger population. Hence, labour-saving technological progress can lead to higher marginal outputs. However, we can see from Figure $4 d$, that the average annual growth in rice prices is $0.57 \%$ in the short term.

In the short term, labour-saving technological progress has an apparent guarantee of food security. However, labour-saving technological progress also leads to increased grain prices due to increased wage rates and capital returns. It cannot offset the price shock in the foreign market and cannot reduce import dependence compared with the other three types of technological progress. The impact of all-factor technological progress is second only to that of labour-saving technological progress, which can increase grain outputs in the short term and reduce fluctuations in grain prices. However, capital-saving technological progress has little effect on output and has almost no impact on grain prices, 
import dependence, and grain output per hectare. Land-saving technology increases the grain output per hectare and reduces the dependence on imported foreign grain. However, the effect is limited in the short run.

(a)

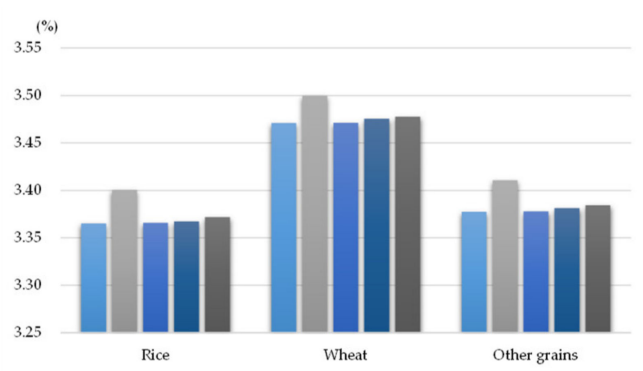

(c)

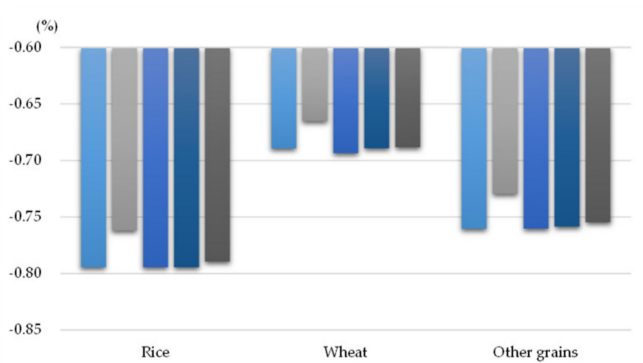

(e)

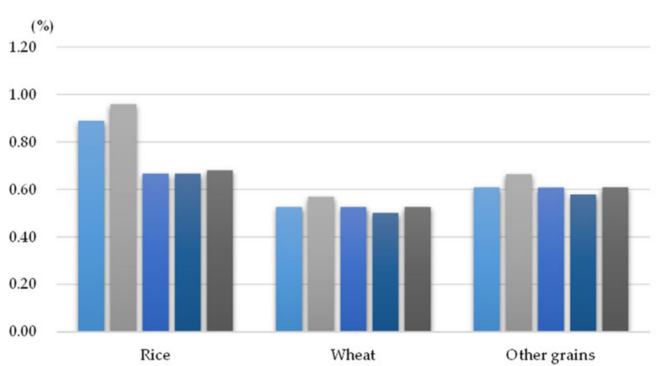

(b)

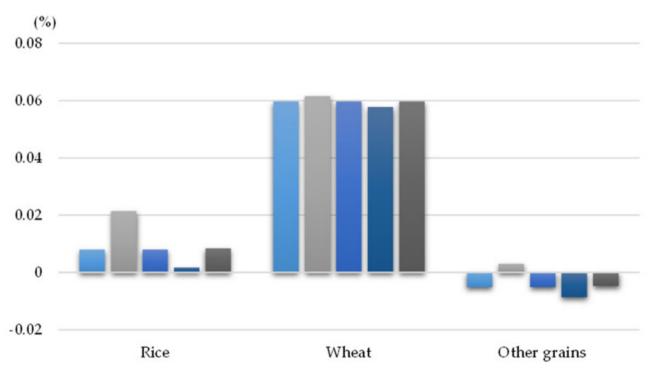

(d)

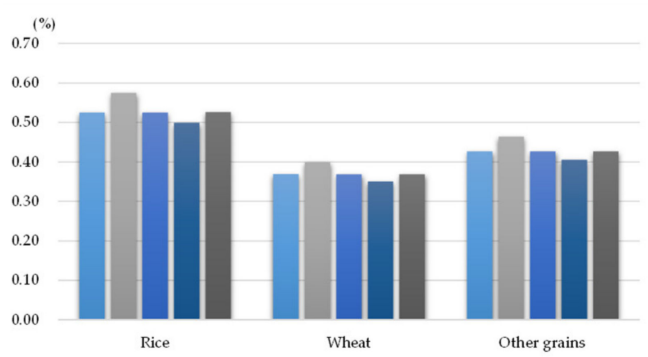

(f)

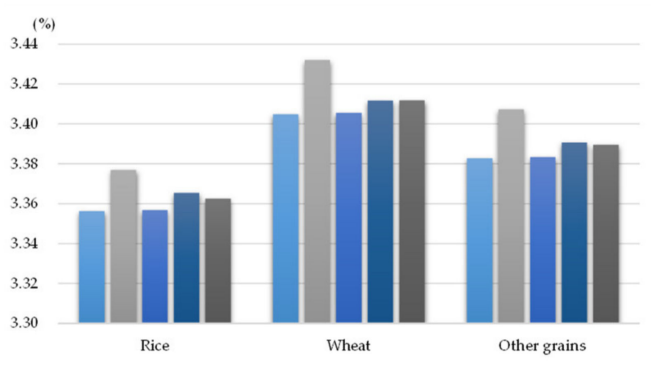

ㅁAㄴ

Figure 4. The average annual rate of food security in the short term under different scenarios (\%). (a) Grain output. (b) Arable land area per capita. (c) Grain consumption per capita. (d) Grain price. (e) Import dependence. (f) Grain output per hectare. The short term refers to the average annual rate of change in various food security indicators from 2020 to 2022.

We are trying to discuss the effects of different technological advancements over a more extended period of time (2020-2030). From a long-term perspective, the positive contribution of the four technological advances to output are greater than that of the short-term technological advances. For example, as to rice output, labour technological progress (L-SET1) contributes $4.76 \%$ to grain output growth, slightly ahead of the other three technological advancements. The difference is narrowing, and they remain between $4.75 \%$ and $4.76 \%$. However, in the long run, the contribution of land-saving technological progress to the arable land area per capita of wheat and other grains is $4.57 \%$ and $4.56 \%$, respectively, which is much higher than the other three technological advancements. In our view, land-saving technological progress leads to increased marginal output and comparatively low land rent. Land use is easy to expand in the long term (See Figure A1, Appendix B). 


\subsection{Macroeconomic Indicator Analysis}

It can be seen from Table 3 that different kinds of technological progress have different impacts on GDP. Labour-saving technological progress contributes the most to GDP growth, followed by all-factor technological progress. In contrast, capital-saving and land-based technological progress have a weak impact on GDP. The cost-effectiveness created by technological progress has increased the consumption of agricultural products by various institutions and departments. Besides this, it has also created a competitive advantage and expanded the total net export volume. Improvements in grain production efficiency affect overall consumption, mainly manifested through labour-saving technological progress. Technological advancement has the most significant effect on stimulating residents' consumption; however, it provides little stimulus to government departments' consumption. Within government consumption, the agricultural sector and its upstream and downstream sectors account for a small proportion (about $0.22 \%$ ).

Table 3. Changes in GDP and CPI under four types of technological progress (\%).

\begin{tabular}{cllllllll}
\hline \multirow{2}{*}{ Scenarios } & \multicolumn{4}{c}{ Short-Run } & \multicolumn{3}{c}{ Long-Run } \\
\cline { 2 - 10 } & SET1 & SET2 & SET3 & SET4 & SET1 & SET2 & SET3 & SET4 \\
\hline GDP & 0.378 & 0.005 & 0.022 & 0.053 & 0.400 & 0.006 & 0.042 & 0.061 \\
CPI & 0.305 & 0.004 & 0.033 & 0.020 & 0.313 & 0.004 & 0.018 & 0.018 \\
\hline
\end{tabular}

Note: The short run means the average level of 2020-2022, and the long run is that of 2020-2030.

With four types of technological progress in the agricultural sector, labour-saving technological progress contributes $0.31 \%$ to the increase in the consumer price index (CPI) in the short term and $0.31 \%$ in the long term (see Table 3). Other types of technological progress have little impact on the CPI. The underlying reason is that increases in production costs are caused by factor prices, which lead to an increase in the CPI. In the short term, improving labour-saving technology will initially reduce labour prices and increase labour demand and production. However, the capital stock is fixed in the short term, and the expansion of production will increase the capital price. In the long run, capital is adjusted following economic growth, and the capital price will decrease compared with that in the short term. Therefore, the long-term increase in CPI triggered by factor prices is slightly smaller than that in the short term. Overall, the macroeconomic effects of labour-saving technological progress are the best, followed by those of all-factor technological progress, land-saving, and capital-based technological progress.

As shown in Figure 5, technological progress increased imports and exports, especially labour-saving technological progress. In the short term, compared with the BAU scenario, imports increased by $0.65 \%$ annually and exports increased by $0.08 \%$. In the long run, imports and exports increased by $0.66 \%$ and $0.11 \%$, respectively. Due to technological progress in the agricultural sector, the grain produced in China will be more competitive with the same goods in the international market, resulting in a decrease in import demand. However, the results show that all four types of technological progress would increase total imports. The reason may be that the cost reductions brought about by technological improvements would lead to an expansion of production, which would require more intermediate inputs. To meet the input needs of production, the demand for imports may increase.

Simultaneously, technological progress in the agricultural sector will cause the price of intermediate inputs to fall, thereby reducing the production costs of downstream industries and improving competitiveness in the international market. In particular, the improvement of labour-saving technology has a greater positive impact on exports, especially in the early stages of technological progress. It means that although the effect of labour-saving technological progress is affected by the increase in factor costs, it will not reduce the competitiveness of China's grain in the world market. As mentioned, capital and labour become expensive in the short term, but the impact on exports is negligible. The impact will 
be even less in the long run because the spillover effects brought about by technological progress will offset the negative effects of increasing production costs. However, technological progress will generally increase imports more than exports but will not reverse the current trade surplus, and have a positive impact on China's trade, but the impact is slight.

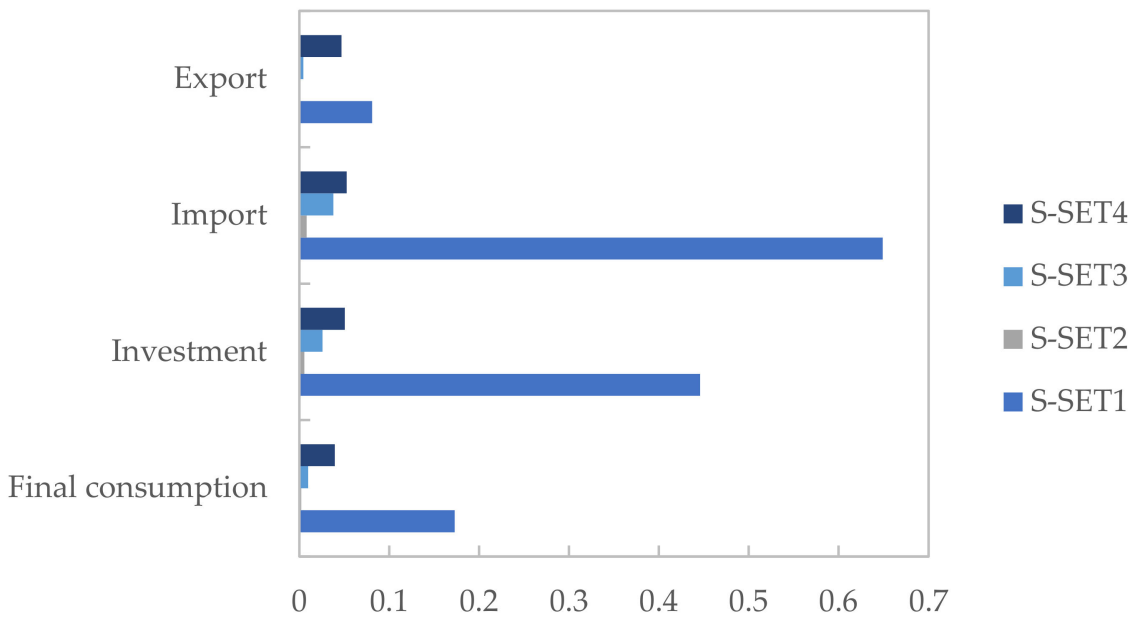

(a) The average annual rate of change in various macro indicators in short term

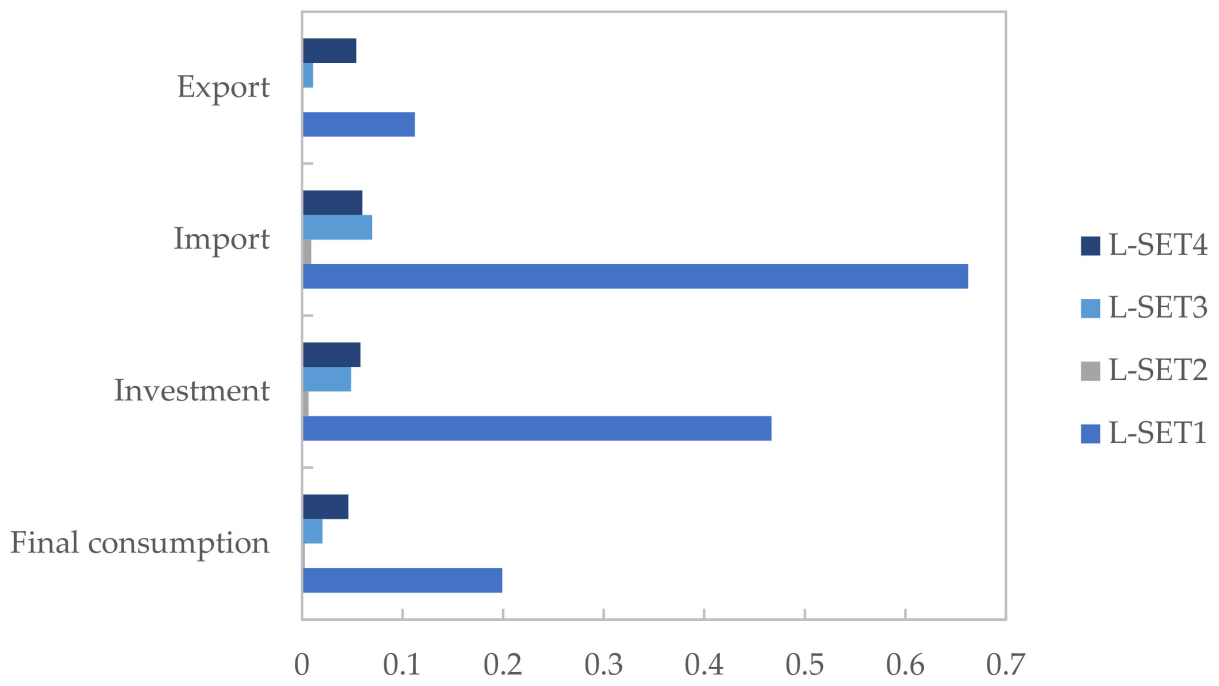

(b) The average annual rate of change in various macro indicators in long term

Figure 5. Macro effects under the four types of technological progress compared with BAU. (a) The short term refers to 2020 to 2022. (b) The long term refers to 2020 to 2030.

\section{Conclusions and Suggestions}

On the basis of the dynamic CGE model and China's SAM table for 2017, we estimated the impact of four types of technological progress on China's food security and macroeconomics in the context of the COVID-19 pandemic. We found a number of results.

First, COVID-19 has had major negative impacts on China's food security in the short term. The output of rice, wheat, and other grains in 2020 decreased by $1.89 \%, 2.08 \%$, and $0.93 \%$ annually compared with non-COVID. The loss is more severe than that in the conclusions of NHC [54], since they only studied the impact of epidemic-affected labour shortages without the loss of productivity. Moreover, without external shocks (such as government subsidies, food policies, technical support, etc.), the epidemic's impact on China's food security indicators will continue for $3-5$ years. 
Second, labour-saving technological progress is the best for ensuring food security and can ensure the steady development of China's food production, which is in line with the conclusions of Zhang, Sun, Wu and Deng [42]. Neutral technological progress is the secondbest for ensuring food security, while capital-saving and land-saving technological progress have little effect. To sum up, labour-saving technological progress is the best contributor to the macroeconomic effects, followed by neutral technological progress, land-saving technological progress, and capital-saving technological progress in the short run. While in the long run, the contribution of the four technological progresses to output is greater than that of the short-term technological advances. Labour technological progress is slightly ahead of the other three technological advancements in grain output. However, as to arable land area per capita in wheat and other grains, land productivity's contribution is much higher than the other three technological advancements. The conclusions are similar to those of Chen, Oxley, $\mathrm{Xu}$, Wang and Ma [40], who found that capital and land productivity have dominated China's wheat production instead of labour-intensive operations. In the short term, our results indicated that increasing labour productivity is a leading contributor to China's agriculture because of the shortage in the labour force during the pandemic.

To cope with the current and future events facing China, this study proposes the following policy suggestions: First, we must recognize that supply-side structural reforms are the essential foundation to improving the labour productivity that is essential to China's food security. Investment in training for the agricultural sector will also enhance the specialised expertise that will enable China's agricultural sector to compete globally and will enable professional farmers to restore abandoned farmland to productivity. Second, when the international grain market is unstable, the government needs to adopt active trade measures to deal with the new trade barriers caused by the COVID-19 epidemic to prevent the risk of possible upward future price trends in the international agricultural products market. Finally, to realize the new development pattern with the main domestic market cycle and the mutual promotion of the domestic and international double market cycles, it is necessary for the government to ensure the self-reliance, independent development, and import dependence of the agricultural sector and reduce the dependence on imported agricultural products through the reforms of agriculture, farmers, and rural areas to stimulate grain production and explore the potential of domestic grain production.

However, the limitation of this article is that technological progress here refers to exogenous factor-saving productivity. For more microscopic practices of technological progress, the model needs more variables and data to define and measure such technological improvement. In the future, some attempts will need to be combined with microeconomics, like linking with specific tech. It will be a challenging but interesting attempt. Besides, some government policy support can be a good topic for future research.

Author Contributions: Conceptualization, X.L.; methodology, X.L. and L.Q.; software, X.L. and L.Q.; validation, X.L. and L.Q.; formal analysis, X.L. and L.Q.; investigation, H.P. and B.S.; resources, X.L. and L.Q.; data curation, X.L. and L.Q.; writing—original draft preparation, X.L. and L.Q.; writing-review and editing, H.P. and B.S.; visualization, X.L. and L.Q.; supervision, H.P. and B.S. All authors have read and agreed to the published version of the manuscript.

Funding: This research was supported by the Beijing Social Science Foundation Project-Construction and Application of Computable General Equilibrium Comprehensive Evaluation Model for EpidemicSocio-Economic Tripartite Linkage in Beijing (Grant No. 20ZDA09).

Institutional Review Board Statement: Not applicable.

Informed Consent Statement: Not applicable.

Data Availability Statement: Not applicable.

Conflicts of Interest: The authors declare no conflict of interest. 


\section{Appendix A}

CGE Model equations

Production module

Production function for goods

$$
X(P S)=A P(P S) *\left[\beta(P S) * U(P S)^{\rho(P S)}+\gamma(P S) * V(P S)^{\rho(P S)}\right]^{\frac{1}{\rho(P S)}}
$$

Production function for intermediate inputs

$$
U(P S)=\sum_{C C} u t(C C, P S) * X X(C C, P S)
$$

Value-added function

$$
\left.V(P S)=A V(P S) *\left[\sum_{f} \gamma(f, P S) * v^{\prime}(f, P S)\right)^{\rho(P S)}\right]^{\frac{1}{\rho(P S)}}
$$

Income and expenditure module

Household

Household income

$$
H Y=W * L S+R * K S+P L A N D * L A N D S+\operatorname{trans} f_{\text {govh }}
$$

Household consumption

$$
H E=\operatorname{shrh}_{\mathcal{~ C C}} *\left(1-t_{h}\right) * H Y
$$

Household saving

$$
H S=\left(1-s h r h_{c c}\right) *\left(1-t_{h}\right) \cdot H Y
$$

Government

Government income

$$
G Y=P T+D V A T+T A R F+I M C T+I M V A T+D C T+D T
$$

Government expenditure for commodities demand

$$
G C=\operatorname{shrg}_{c c} *\left(Y G-\text { transfr } r_{g_{h}}\right)
$$

Government saving

$$
G S=\left(1-\operatorname{shrg}_{c c}\right) *\left(Y G-\text { transf }_{g_{h}}\right)
$$

Trade Module

Armington function between imports and domestic goods

$$
Q C(C C)=A A(C C) *\left[\delta(C C) * Q D(C C)^{\rho(C C)}+(1-\delta(C C)) * I M P(C C)^{\rho(C C)}\right]^{\frac{1}{\rho(C C)}}
$$

CET function between exports and domestic goods

$$
Q(C C)=A T(C C) *\left[\varepsilon(C C) \cdot Q D(C C)^{\rho(C C)}+(1-\varepsilon(C C)) * E X P(C C)^{\rho(C C)}\right]^{\frac{1}{\rho(C C)}}
$$

Dynamic module

Capital stock growth

$$
K S(T H+1)=(1-\text { dep }) * K S(T H)+N I N V(T H)
$$


Labor supply growth

$$
L S(T H+1)=(1+g \operatorname{pop}(T H)) * L S(T H)
$$

Close module

Commodity market balance

$$
Q(C C)=\sum_{P S} X X(P S, C C)+H C(C C)+G C(C C)+I N V(C C)+S C(C C)
$$

Factor markets balance

$$
\begin{aligned}
& L S=\overline{L D} \\
& K S=\overline{K D}
\end{aligned}
$$

Saving/investment balance

$$
I N V=H S+G S
$$

Trade closure

$$
P E X P \cdot E X P=P I M P * I M P+I N V F
$$

Technological change

Value added function

According to Acemoglu (2007), we use $\theta(f)$ to represent the biased technological

\begin{tabular}{|c|c|c|c|}
\hline Variables & Descriptions & Variables & Descriptions \\
\hline $\mathrm{X}(\mathrm{PS})$ & Domestic Output & DT & Individual Income Tax \\
\hline $\mathrm{V}(\mathrm{PS})$ & Capital and labor input & QC & $\begin{array}{l}\text { Quantity of Composite commodity supplied to or consumed in } \\
\text { domestic market }\end{array}$ \\
\hline $\mathrm{U}(\mathrm{PS})$ & Intermediate input & QD & $\begin{array}{l}\text { Quantity of domestically-produced commodity sold in } \\
\text { domestic market }\end{array}$ \\
\hline $\mathrm{XX}(\mathrm{PS}, \mathrm{CC})$ & Intermediate input matrix & Q & Quantity of domestically-produced commodity \\
\hline $\mathrm{KD}$ & Capital demand & $\mathrm{IMP}$ & Import \\
\hline LS & Labour supply & EXP & Export \\
\hline LD & Labour demand & PEXP & Price of export \\
\hline Land & Land input & PIMP & Price of import \\
\hline $\mathrm{R}$ & Capital price & EXR & Exchange rate \\
\hline $\mathrm{W}$ & Wage rate & INVF & Foreign investment \\
\hline Pland & Price of land & $\mathrm{AP}(\mathrm{PS})$ & Scaling parameter of CES production function for producer \\
\hline HY & Household income & AV(PS) & Scaling parameter of CES function of factor inputs \\
\hline $\mathrm{HC}$ & Household consumption & $\mathrm{AA}(\mathrm{CC})$ & Scaling parameter of Armington function \\
\hline HS & Household saving & $\mathrm{AT}(\mathrm{CC})$ & Scaling parameter of Transformation function \\
\hline trans $f_{\text {govh }}$ & Expenditure of the government transfers & $\beta(P S)$ & Substitution rate of intermedia input \\
\hline GY & Government income & $\gamma(P S)$ & Substitution rate of value-added input \\
\hline GC & Government consumption & $\rho(P S)$ & Substitution elasticity \\
\hline GS & Government saving & $\delta(C C)$ & Substitution rate of Armington assumption \\
\hline PT & Production tax & $\varepsilon(C C)$ & Substitution rate of transformation assumption \\
\hline DVAT & Domestic VAT & $u t(C C, P S)$ & Table of intermediate inputs or uses \\
\hline TARF & Import tariffs & $\gamma(f, P S)$ & Substitution rate of factor input \\
\hline IMCT & $\begin{array}{l}\text { Income from consumption tax on } \\
\text { imported commodities }\end{array}$ & $\operatorname{shrh}_{c c}$ & Composition of household consumption \\
\hline IMVAT & Income from VAT on imported goods & $t_{h}$ & Proportion of government transfer to household \\
\hline DCT & $\begin{array}{l}\text { Income from consumption tax on } \\
\text { domestic goods }\end{array}$ & $\operatorname{shrg} c c$ & Composition of government consumption \\
\hline
\end{tabular}
progress rate of factor $f$. Therefore, we simulated the progress of agricultural technology in four different simulations by changing $A V(P S)$ and $\theta(f)$.

$$
\left.V(P S)=A V(P S) *\left[\sum_{f} \gamma(f, P S) * \theta(f) * v^{\prime}(f, P S)\right)^{\rho(P S)}\right]^{\frac{1}{\rho(P S)}}
$$

Table A1. Definition of the variables in equations. 


\section{Appendix B}

(a)

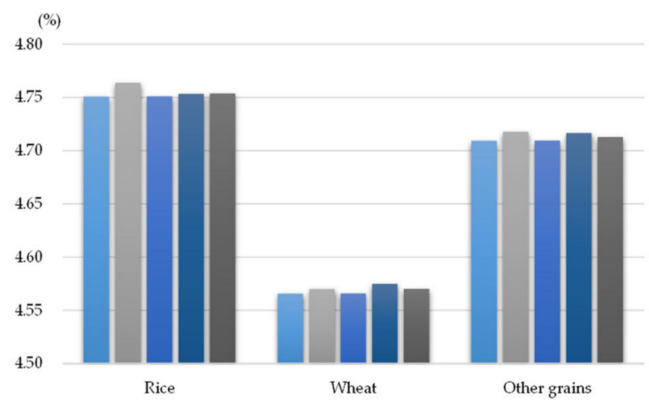

(c)

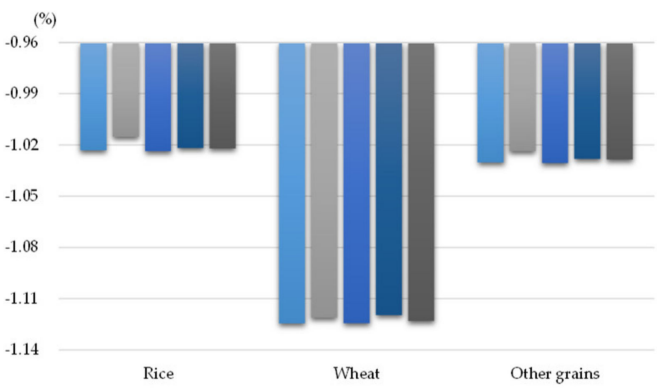

(e)

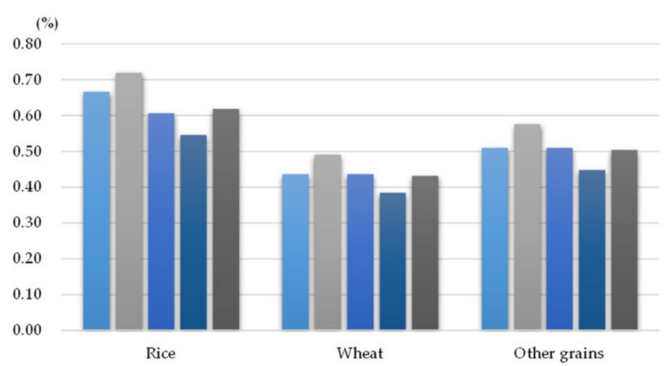

(b)

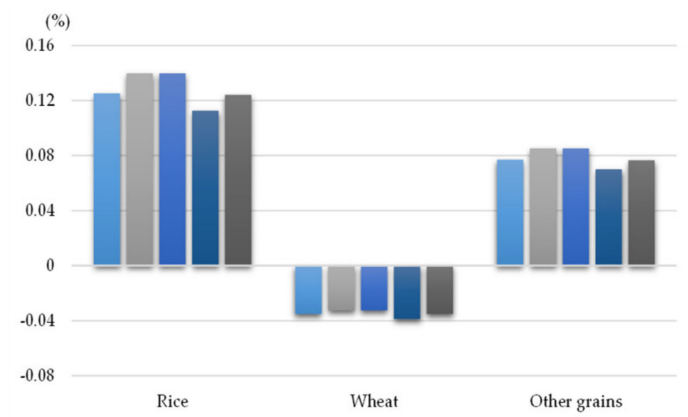

(d)

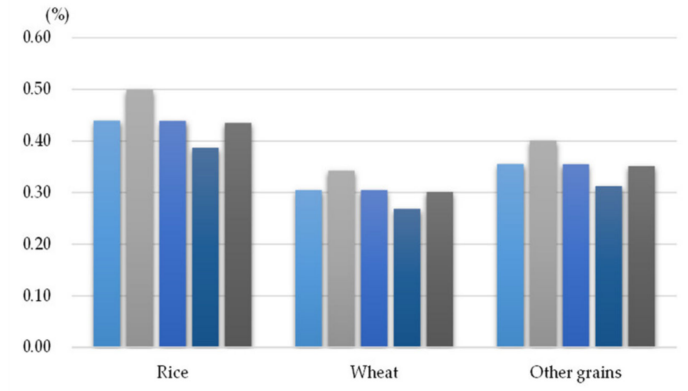

(f)

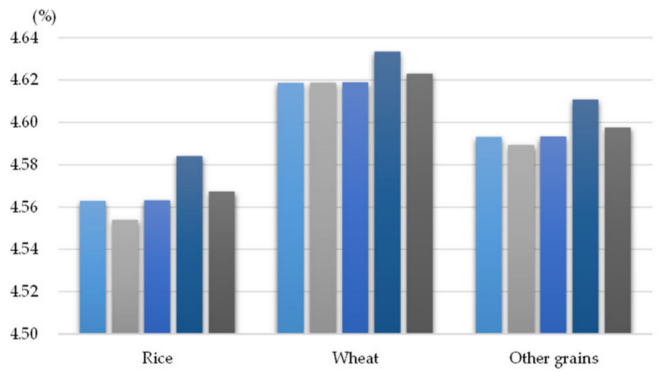

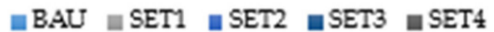

Figure A1. The average annual rate of food security in long run under different scenarios. (a) Grain output. (b) Arable land area per capita. (c) Grain consumption per capita. (d) Grain price. (e) Import dependence. (f) Grain output per hectare. The short term refers to the average annual rate of change in various food security indicators from 2020 to 2030.

\section{References}

1. Yu, Z.; Razzaq, A.; Rehman, A.; Shah, A.; Jameel, K.; Mor, R.S. Disruption in global supply chain and socio-economic shocks: A lesson from COVID-19 for sustainable production and consumption. Oper. Manag. Res. 2021, 1-16. [CrossRef]

2. Helm, D. The environmental impacts of the coronavirus. Environ. Resour. Econ. 2020, 76, 21-38. [CrossRef]

3. Devereux, S.; Béné, C.; Hoddinott, J. Conceptualising COVID-19's impacts on household food security. Food Secur. 2020, 12, 769-772. [CrossRef] [PubMed]

4. Xu, J.; Wei, W. The effects of tax and fee reduction policy on mitigating shock of the COVID-19 epidemic in China. Appl. Econ. 2021, 53, 5303-5318. [CrossRef]

5. Torero, M. Without food, there can be no exit from the pandemic. Nature 2020, 580, 588-589. [CrossRef] [PubMed]

6. Erokhin, V.; Gao, T. Impacts of COVID-19 on trade and economic aspects of food security: Evidence from 45 developing countries. Int. J. Environ. Res. Public Health 2020, 17, 5775. [CrossRef]

7. Pérez-Escamilla, R.; Cunningham, K.; Moran, V.H. COVID-19, food and nutrition insecurity and the wellbeing of children, pregnant and lactating women: A complex syndemic. Matern. Child Nutr. 2020, 16, e13036. [CrossRef] [PubMed] 
8. Liang, L.; Qin, K.; Jiang, S.; Wang, X.; Shi, Y. Impact of Epidemic-Affected Labor Shortage on Food Safety: A Chinese Scenario Analysis Using the CGE Model. Foods 2021, 10, 2679. [CrossRef] [PubMed]

9. Fan, S.; Teng, P.; Chew, P.; Smith, G.; Copeland, L. Food system resilience and COVID-19-Lessons from the Asian experience. Glob. Food Secur. 2021, 28, 100501. [CrossRef]

10. Roser, M.; Ritchie, H. Hunger and Undernourishment. Our World Data. 2019. Available online: https://ourworldindata.org/ hunger-and-undernourishment (accessed on 1 June 2020).

11. Fleetwood, J. Social justice, food loss, and the sustainable development goals in the era of COVID-19. Sustainability 2020, 12, 5027. [CrossRef]

12. Pangestu, M.E. Hunger Amid Plenty: How to Reduce the Impact of COVID-19 on the World's Most Vulnerable People. World Bank Blogs. 2020. Available online: https:/ /blogs.worldbank.org/voices/hunger-amid-plenty-how-reduce-impact-covid-19 -worlds-most-vulnerable-people (accessed on 1 June 2020).

13. Zhan, Y.; Chen, K.Z. Building resilient food system amidst COVID-19: Responses and lessons from China. Agric. Syst. 2021, 190, 103102. [CrossRef]

14. Jiang, S.; Wang, J.; Zhao, Y.; Shang, Y.; Gao, X.; Li, H.; Wang, Q.; Zhu, Y. Sustainability of water resources for agriculture considering grain production, trade and consumption in China from 2004 to 2013. J. Clean. Prod. 2017, 149, 1210-1218. [CrossRef]

15. Mukhopadhyay, K.; Thomassin, P.J.; Zhang, J. Food security in China at 2050: A global CGE exercise. J. Econ. Struct. 2018, 7, 1. [CrossRef]

16. Wang, Y. The challenges and strategies of food security under rapid urbanization in China. Sustainability 2019, 11, 542. [CrossRef]

17. China State Council. Comprehensively Promoting Rural Revitalization and Accelerating Agricultural and Rural Modernization. CSC. 2020. Available online: http://www.gov.cn/zhengce/2020-02/05/content_5474884.htm (accessed on 2 January 2020). (In Chinese)

18. Guo, L.; Dai, Z. Study of total factor productivity on China's science and technology service industry: Provincial efficiency comparatively using 2010-2019 data. Appl. Econ. 2021, 53, 5917-5928. [CrossRef]

19. Ginsburgh, V.; Keyzer, M. The Structure of Applied General Equilibrium Models; MIT Press: Cambridge, MA, USA, 2002.

20. Ahmed, F.; Islam, A.; Pakrashi, D.; Rahman, T.; Siddique, A. Determinants and Dynamics of Food Insecurity During COVID-19 in Rural Bangladesh. Food Policy 2021, 101, 102066. [CrossRef]

21. Adjognon, G.S.; Bloem, J.R.; Sanoh, A. The Coronavirus Pandemic and Food Security: Evidence from Mali. Food Policy 2021, 101, 102050. [CrossRef]

22. Folayan, M.O.; Ibigbami, O.; El Tantawi, M.; Brown, B.; Aly, N.M.; Ezechi, O.; Abeldaño, G.F.; Ara, E.; Ayanore, M.A.; Ellakany, P. Factors Associated with Financial Security, Food Security and Quality of Daily Lives of Residents in Nigeria during the First Wave of the COVID-19 Pandemic. Int. J. Environ. Res. Public Health 2021, 18, 7925. [CrossRef] [PubMed]

23. $\mathrm{Pu}, \mathrm{M}$; Z Zhong, Y. Rising concerns over agricultural production as COVID-19 spreads: Lessons from China. Glob. Food Secur. 2020, 26, 100409. [CrossRef] [PubMed]

24. Deng, X.; Zeng, M.; Xu, D.; Qi, Y. Does Social Capital Help to Reduce Farmland Abandonment? Evidence from Big Survey Data in Rural China. Land 2020, 9, 360. [CrossRef]

25. Sukhwani, V.; Deshkar, S.; Shaw, R. Covid-19 lockdown, food systems and urban-rural partnership: Case of Nagpur, India. Int. J. Environ. Res. Public Health 2020, 17, 5710. [CrossRef] [PubMed]

26. Lahcen, B.; Brusselaers, J.; Vrancken, K.; Dams, Y.; Paes, C.D.S.; Eyckmans, J.; Rousseau, S. Green recovery policies for the COVID-19 crisis: Modelling the Impact on the economy and greenhouse gas emissions. Environ. Resour. Econ. 2020, 76, 731-750. [CrossRef] [PubMed]

27. Nechifor, V.; Ramos, M.P.; Ferrari, E.; Laichena, J.; Kihiu, E.; Omanyo, D.; Musamali, R.; Kiriga, B. Food security and welfare changes under COVID-19 in Sub-Saharan Africa: Impacts and responses in Kenya. Glob. Food Secur. 2021, 28, 100514. [CrossRef]

28. Beckman, J.; Countryman, A.M. The Importance of Agriculture in the Economy: Impacts from COVID-19. Am. J. Agric. Econ. 2021, 103, 1595-1611. [CrossRef]

29. Han, X.; Chen, Y.; Wang, X. Impacts of China's bioethanol policy on the global maize market: A partial equilibrium analysis to 2030. Food Secur. 2021, 1-17. [CrossRef] [PubMed]

30. Zhang, Y.; Diao, X.; Chen, K.Z.; Robinson, S.; Fan, S. Impact of COVID-19 on China's macroeconomy and agri-food system-an economy-wide multiplier model analysis. China Agric. Econ. Rev. 2020, 12, 387-407. [CrossRef]

31. Schiersch, A.; Belitz, H.; Gornig, M. Why is TFP growth sectorally concentrated? Appl. Econ. 2015, 47, 5933-5944. [CrossRef]

32. Vandenberghe, V. The productivity challenge. What to expect from better-quality labour and capital inputs? Appl. Econ. 2017, 49, 4013-4025. [CrossRef]

33. Hicks, J. The Theory of Wages; Springer: Berlin/Heidelberg, Germany, 1963.

34. Acemoglu, D. Equilibrium bias of technology. Econometrica 2007, 75, 1371-1409. [CrossRef]

35. Nin, A.; Arndt, C.; Preckel, P.V. Is agricultural productivity in developing countries really shrinking? New evidence using a modified nonparametric approach. J. Dev. Econ. 2003, 71, 395-415. [CrossRef]

36. Acemoglu, D. Technical change, inequality, and the labor market. J. Econ. Lit. 2002, 40, 7-72. [CrossRef]

37. Geylani, P.C.; Stefanou, S.E. Productivity growth patterns in US dairy products manufacturing plants. Appl. Econ. 2011, 43, 3415-3432. [CrossRef]

38. Kim, S.; Lim, H.; Park, D. Imports, exports and total factor productivity in Korea. Appl. Econ. 2009, 41, 1819-1834. [CrossRef] 
39. Oh, D.; Heshmati, A.; Lööf, H. Technical change and total factor productivity growth for Swedish manufacturing and service industries. Appl. Econ. 2012, 44, 2373-2391. [CrossRef]

40. Chen, S.; Oxley, L.; Xu, Z.; Wang, Y.; Ma, H. The dynamic adjustment of factor inputs and its policy implications for major wheat producing areas in China. Econ. Model. 2013, 33, 450-457. [CrossRef]

41. Key, N. Farm size and productivity growth in the United States Corn Belt. Food Policy 2019, 84, 186-195. [CrossRef]

42. Zhang, Q.; Sun, Z.; Wu, F.; Deng, X. Understanding rural restructuring in China: The impact of changes in labor and capital productivity on domestic agricultural production and trade. J. Rural Stud. 2016, 47, 552-562. [CrossRef]

43. Valin, H.; Havlík, P.; Mosnier, A.; Herrero, M.; Schmid, E.; Obersteiner, M. Agricultural productivity and greenhouse gas emissions: Trade-offs or synergies between mitigation and food security? Environ. Res. Lett. 2013, 8, 035019. [CrossRef]

44. Johansen, L. Multi-Sectoral Study of Economic Growth; North-Holland Publishing, Co.: Amsterdam, The Netherlands, 1960.

45. UNDESA (United Nations Department of Economic and Social Affairs). World Population Prospects: The 2017 Revision. 2017. Available online: https://www.un.org/development/desa/publications/world-population-prospects-the-2017-revision.html (accessed on 21 June 2017).

46. Hertel, T.W. Applied general equilibrium analysis of agricultural and resource policies. Handb. Agric. Econ. 2002, 2, $1373-1419$.

47. Ma, J.; Zhang, X.; Gu, H. A study on assessment indexes for the alert system of food security. Manag. World 2001, 1, 154-162.

48. Fan, G. China's Food Safety Measure: An Indicator System. Econ. Theory Bus. Manag. 2005, 12, 5.

49. Cullen, M.T. COVID-19 and the Risk to Food Supply Chains: How to Respond; FAO: Rome, Italy, 2020.

50. Sarkar, A.; Hongyu, W.; Jony, A.A.; Das, J.C.; Memon, W.H.; Qian, L. Evaluation of the determinants of food security within the COVID-19 pandemic circumstances-a particular case of Shaanxi, China. Glob. Health Res. Policy 2021, 6, 45. [CrossRef] [PubMed]

51. Barichello, R. The COVID-19 pandemic: Anticipating its effects on Canada's agricultural trade. Can. J. Agric. Econ./Rev. Can. D'agroecon. 2020, 68, 219-224. [CrossRef]

52. Dixon, P.B.; Lee, B.; Muehlenbeck, T.; Rimmer, M.T.; Rose, A.; Verikios, G. Effects on the US of an H1N1 epidemic: Analysis with a quarterly CGE model. J. Homel. Secur. Emerg. Manag. 2010, 7, 1.

53. McKibbin, W.; Fernando, R. The global macroeconomic impacts of COVID-19: Seven scenarios. Asian Econ. Pap. 2020, 20,1-30. [CrossRef]

54. NHC (National Health Commission of the People's Republic of China). Notification of 2019-nCoV Infection. 2020. Available online: http:/ / www.nhc.gov.cn/xcs/yqtb /202012/f3065d86524a4202a1384ed6b9b9f2b5.shtml (accessed on 31 December 2020).

55. $\mathrm{Wu}, \mathrm{X}$; Guo, J. Comprehensive economic loss assessment of disaster based on CGE model and IO model—A case study on Beijing “7.21 Rainstorm”. In Economic Impacts and Emergency Management of Disasters in China; Springer: Singapore, 2021; pp. 105-136.

56. NBS (National Bureau of Statistics). National Annual Statistical Bulletin. Available online: http://www.stats.gov.cn/tjsj/tjgb/ ndtjgb / (accessed on 1 June 2020).

57. Yao, H.; Zuo, X.; Zuo, D.; Lin, H.; Huang, X.; Zang, C. Study on soybean potential productivity and food security in China under the influence of COVID-19 outbreak. Geogr. Sustain. 2020, 1, 163-171. [CrossRef]

58. Antonelli, C.; Quatraro, F. The effects of biased technological change on total factor productivity: Empirical evidence from a sample of OECD countries. J. Technol. Transf. 2010, 35, 361-383. [CrossRef] 